\title{
トンネル施工における地下水環境保全
}

\author{
西垣 誠*

\section{Environmental protections of the groundwater depending on the constructions of the tunnel}

\author{
Makoto NISHIGAKI*
}

\begin{abstract}
Author explained the influence of the construction of tunnels and underground structures on the groundwater environment, and the influence of groundwater on the tunnel construction, based on past cases. In addition, an overview of the history of new construction techniques that have been developed so far to prevent the adverse effects of tunnel construction on the groundwater environment was also presented. In particular, author described various construction methods for each of the water cut-off method and drainage method,their difficulties, and how to use them properly according to the situation at the site.
\end{abstract}

Key Words: tunnel, groundwater, grouting, environment conservation, ground collapse, shield

\section{要旨}

トンネルや地中構造物を施工することによって地下水環境に与える影響, また, 地下水がトンネル 施工時に与える影響について, 過去の事例を踏まえながらその対応の歴史を解説した。さらに, トン ネル施工が地下水環境へ及ぼす悪影響を防ぐために, これまで開発されてきた新しい施工技術の歴 史についても概観した。特に, 止水方法, 水抜き方法それぞれの様々な施工方法とその難しさ, また 現場の状況に応じてどのように使い分けるべきか等の考え方について述べた。

キーワード：トンネル, 地下水, グラウト, 環境保全, 地盤陥没, シールド

1.はじめに

国土の 7 割が森林である日本では，限られた平 野部をより有効に活用するために, 道路や鉄道等 のライフラインを地下に施工する必要がある。ま たトンネルを掘削して, 地下空間で原油や天然
ガスを常温で備蓄する国家プロジェクトも実施さ れている。

高速道路では, 古くは橋梁による施工が主で あった。しかし，1995年 1 月17日の阪神淡路大震 災で, 高速道路の多くの高架橋で橋脚のせん断破 壊による倒壊が生じてしまった。これ以後, 高架

* 岡山大学名誉教授

Okayama University Emeritus Professor 
橋による高速道路から, 地中のトンネルによる高 速道路へと変更され，2018年 6 月 2 日に東京外か く環状道路 (外環道) の東側区間（三郷南 IC か ら高屋 JCT）が開通した。この道路は, 阪神淡 路大震災後, 最初に建設された半地下（道路上 部がストラット状に開口されたU字型の地下道 路）の道路である（上山ほか，2016）。このよう な構造物は, トンネルではないが地中構造物であ るため, 常に地下水の流動阻害を検討して設計さ れた。同様に, 外環道の西側区間では, 全線がほ ぼシールド工法で施工されており, 約 $5 \mathrm{~km}$ 区間 おきに IC・JCT を設けて地上に構造物の頂部が 出る構造になっている。この場合も, 地中構造物 等による地下水への流動阻害を， 3 次元の有限要 素法による数值解析によって予め検討している。 すなわち, 地下水の流動阻害が生じる場所では, 上流側から浸透してくる地下水をスムーズに下流 側に流動させるため, 構造物の周囲に地下水を流 動させるバイパスを多数設置して, 地中構造物の 上流側と下流側の水位差を許容範囲に収める対策 を講じる設計にして工事を行っている。このよう な対策は, 構造物の上流側の水位が上昇すること による地震時の砂質地盤の液状化対策となり，ま た, 地下水の流動阻害によって生じる下流の井戸 の枯渴や粘土層の地盤沈下等を回避する対策に なっている（地盤工学会編, 2004 ; 茂利ほか, 2005)。

2018年に地盤工学会誌（Vol.66, No.2）で「ト ンネル／地下構造物」の特集が久しぶりに組まれ た。総説, 論説, 報告を含んで 8 編の報文が掲載
されているが，地下水に関しては 1 編の報文だけ であった。しかし，トンネル掘削において地下水 の挙動の把握は最も大切な事であり, その対策を 誤ると甚大な事故に繋がる問題であるが，いまだ 根本的な解決策がないのが現状で, 未知な地盤の 中でトンネル工事がなされていると言っても過言 ではない。

本報文では，このようなトンネルや地中構造物 を施工することによって, 地下水が自然環境に与 える影響や, 地下水がトンネル施工時やその後に 与える影響について論述する。

\section{2. トンネル工事が地下水および地表環境に与 える影響}

\section{1 排水構造のトンネル工事が地下水位およ び地表面高さに与える影響}

トンネルを掘削する際は, 地山内にある地下水 をどのように処理するかが大きな課題であった。

トンネル内に湧水してくる地下水の排水に関して は，表2-1に示すように地表からの対策やトンネ ル内からの対策がなされてきた。

都市部の地下水位低下による地盤沈下等が生じ る所においては, 現状ほとんどシールド工法が適 用されており，トンネル掘削工事は，地下水への 変動の影響がほとんどないように施工されてい る。しかし, 近年, このようなシールド工事の直 径が $13 \mathrm{~m}$ 近くになり, 地下水の流動を阻害する と考えられる所は, 綿密な地下水調査により 3 次 元で流動保全対策（地盤工学会編，2004）を検討

表 2-1 トンネル掘削工事における地下水対策

\begin{tabular}{|c|c|c|}
\hline 分類 & 対策手法 & 具体的な手法 \\
\hline \multirow[t]{2}{*}{ 地表からの対策 } & 排水工法 & $\begin{array}{l}\text { ·ディープウェル工法 } \\
\text { • ウェルポイント工法 }\end{array}$ \\
\hline & 止水工法 & $\begin{array}{l}\text { ・セメント系溶液系材料 } \\
\text { の注入工法 }\end{array}$ \\
\hline \multirow[t]{2}{*}{ トンネル内からの対策 } & 排水工法 & $\begin{array}{l}\text { ・先進水抜きボーリング } \\
\text { 工法 }\end{array}$ \\
\hline & $\begin{array}{l}\text { 湧水流量軽減工法 } \\
\text { (止水工法) }\end{array}$ & $\begin{array}{l}\text { ・プレグラウト工法 } \\
\text { (セメント系溶液系材 } \\
\text { 料の注入工法) } \\
\text { ・ポストグラウト工法 }\end{array}$ \\
\hline
\end{tabular}


した後，トンネル工事が実施されている。

一方, 山岳トンネル工事では, 現在でも施工性 や安全性を確保するために, 排水工法が選択され ていることが多い。表2-2に山岳トンネル施工に 伴って発生した地下水環境変化と地面陥没事象に ついて公表されている事例を示す。この表は20数 年前に集められた事例であるが，その後も色々な 所で排水工法による地表水 (河川水) の枯渇や地 表沈下現象が生じている。丹那トンネルによる丹 那盆地の地下水枯渴や，そこに住んでいる方々の 生活については，1987年に吉村昭が「闇を裂く道」 と題した小説を出版している（吉村，2016）。

吉村昭はこの小説の中で, 1910年代の東海道本 線の丹那トンネル（熱海から三島間）工事に対 し，トンネル掘削によるトンネル上部の地区の生 活への影響について, 詳細に資料を集め記述して いる。16年もの長い期間をかけての鉄道工事であ
り，丹那盆地にどのようなことが生じたかが記録 されている。一方村上らも, トンネル完成後50年 近く経って現地がどのようになっているかを調査 して，その報告をしている（村上ほか，1977）。 その当時は, トンネル工事によって湧水してくる 地下水を止水する技術が確立されていなかったこ とから, 掘削の安全のために排水工法が用いられ たと考えられる。

湧水流量が多いと予測されたことから, 山陽新 幹線安芸トンネル, 中部縦貫自動車道, 九州新幹 線八代から水俣間などはルートを変更したと報告 されている（例えば, 大島, 2002)。また，地下 鉄工事においても，工事による周辺地下水等の影 響を回避するために京都地下鉄烏丸線の北山から 国際会館までのルートを変更した例がある（梅田 ほか, 1997)。

\section{表 2-2 トンネルに伴う地下水環境問題の公表事例}

\begin{tabular}{|c|c|}
\hline 名称 & 事象 \\
\hline $\begin{array}{r}\text { 東海道本線丹那トンネル }{ }^{5), 6)} \\
\text { 新丹那トンネル }\end{array}$ & $\begin{array}{l}\text { 直上民家の亀裂・傾斜 } \\
\text { 丹那盆地の地下水枯渇現象* }\end{array}$ \\
\hline 湖西線雄琴第 3 トンネル & 直上民家の亀裂・傾斜 \\
\hline 東大阪生駒トンネル & 直上地上部で直径約 $30 \mathrm{~m}$ の陥没 \\
\hline 名神高速道路新天王山トンネル & タケノコ生産量の低下 \\
\hline 山陽新幹線六甲トンネル上ケ原工区 ${ }^{7)}$ & 地上部の沈下 \\
\hline 山陽新幹線福岡トンネル ${ }^{8)}$ & 地上部かんがい用水減少 \\
\hline 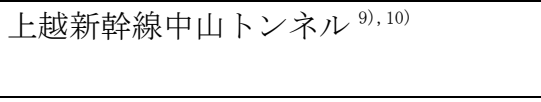 & $\begin{array}{l}\text { 地上部での飲料用水・かんがい用水の } \\
\text { 減少，河川污濁，養魚場への影響 }\end{array}$ \\
\hline 神戸市道新神戸トンネル ${ }^{11)}$ & $\begin{array}{l}\text { 地上部飲料用水・かんがい用水の減 } \\
\text { 少。リクリエーション用池水位低下 }\end{array}$ \\
\hline 高千穂線高森トンネル ${ }^{12)}$ & $\begin{array}{l}\text { 地上部飲料用水・かんがい用水・酒造 } \\
\text { 用水等の減少 }\end{array}$ \\
\hline 国道 19 号新鳥居トンネル ${ }^{13)}$ & 飲料用水減少, 枯渇 \\
\hline J R 中央線塩嶺トンネル ${ }^{14)}$ & 生活用水, かんがい用水減少等 \\
\hline $\begin{array}{l}\text { 中国縦貫自動車道牛頭山トンネル他 } \\
\text { 15) }\end{array}$ & かんがい用水減少 \\
\hline 中央自動車道塩尻トンネル ${ }^{16)}$ & $\begin{array}{l}\text { 生活用水, かんがい用水減少, 水田沈 } \\
\text { 下等 }\end{array}$ \\
\hline 主要地方道・湖陵掛合線才谷トンネル & 地上部生活用水の減少 \\
\hline $\begin{array}{l}\text { 中国電力新熊見発電所導水路トンネ } \\
\text { ル }{ }^{17)}\end{array}$ & $\begin{array}{l}\text { 地上部での飲料用水・かんがい用水の } \\
\text { 減少 }\end{array}$ \\
\hline
\end{tabular}

（*は 4）の文献に一部加筆項目） 


\section{2 地表の水環境と生態系への影響}

トンネル工事による地下水位低下が地表の生態 系へ与える影響を検討することは, 一般に難しい 課題である。自然界には「定常」ということはな く, 常に「非定常」であり, 例えば年によって降 水の降り方も異なり, 気温の変化も異なるため, 地下水への涵養量や蒸発散量の変動を都度詳細に 評価することは難しい。表2-3に排水構造のトン ネル工事による周辺環境への影響を改めて整理し たが, 地下水位, 水圧, 浸透方向の変化 (水平方 向の浸透からトンネル方向の浸透へ), 湧水や地 表水の減少・枯渇, トンネル上部の河川流量の減 少, 河川水の水質の変化, 水温の変化に対して, 生態系がどのように変化したかを知るには，トン ネル工事の数十年前から施工中にわたるルート沿 いの地表生態系の総合的な調査が必要である。ま た，特に地下水による生態系の変化は比較的長時 間経過後に現れることから, 工事後の数十年間に わたる生態系の調査が必要である。しかし, 一般 には，よほど貴重な天然記念物が生育していない かぎり, 工事数十年間にわたる調査が実施される ことはない。

トンネル工事後に色々な作物が採れなくなった との問題が生じて，その対策が必要となる事があ る。これに対して，本当に地下水位が低下したか を確認するために，観測井を設置して観測井間の 水位（水圧）を計測しているが，先にも述べたよ うに，排水型のトンネルを施工すると，地下水の 浸透はトンネルの方向になるため, 観測井の深度 が深いほど観測井内の水位が低くなる現象が生じ
る。これらの深さが異なる観測井内の水位は, ト ンネル掘削前まではそれほど水位差はないことが 多い。観測井内の水位は, 観測区間（ストレーナ 区間あるいは観測井周囲にフィルターを設けた場 合その設置区間）の水圧の平均的な值を示してい る。したがって本来は, 複数の間隙水圧計で複数 の深度の水圧を計測して, トンネル掘削による地 下水位への影響を議論すべきである。さらに，水 環境や生態系の論議をするには, 施工前に複数深 度の観測井を設置し，地表 $1 \mathrm{~m}$ 程度の深さまでの 土壤水分量の変化を事前に長期計測することが有 効である。著者の経験では，トンネル掘削によっ て地下水位が低下したとしても, 地下の土壤水分 量は年間降雨が $1800 \mathrm{~mm}$ 程度である地域では, そ れほど大きな変化なかった。無論, この計測結果 が生態系にどれほど影響しているかいないかは, 生態系の専門家に判断していただく必要がある。

\section{3 排水構造トンネル湧水の有効利用}

丹那トンネルのトンネル内湧水は, 熱海市に供 給され, 現在も温泉地の発展に貢献している（村 上ほか，1977）。高千穂鉄道高千穂線（宮崎県） の高森トンネルの工事は, 度重なる出水事故で貫 通しないまま中止になったが, 坑道は高森湧水卜 ンネル公園になり, 約 $32 \mathrm{~m}^{3} /$ 分程度の湧水は高森 町の水源として利用されている。なお余談である が，高千穂線は1935年に開業されたが，2005年の 台風14号の被害で運休になり，2008年12月に全線 廃止になっている。

現在のトンネル工事は NATM 工法が多く, 岩

\section{表 2-3 排水構造のトンネル工事による周辺環境への課題}
(1) 地上の湧水の枯渇
(2) 地上の池の枯渴
(3) 地上の河川流量の減少
(4) 滝の流量の減少
（5）地表層の地下水位低下による井戸の枯渇
（6）地表層の水分量の変化による生態系の変化
(7) 地上の河川流量の低下による農業用水の減少
（8）地下水の低下による地盤沈下現象
（9）地下水の低下による地盤陷没現象
(10) トンネル内からの湧水による河川水の水質悪化
(11) トンネル内からの湧水による河川水の水温変化 
盤掘削後, 吹き付け工で一次覆工をして, その後 排水層を形成して二次覆工を施工するため，トン ネル内の地下水はコンクリートの吹付等がなされ た一次覆工を浸透してくる場合が多く, pH10程 度のアルカリ水になることが多い。このようなト ンネル湧水を現地で処理して中性にする手法（古 家，2012）もあるが，トンネルへの湧水を有効利 用するのであれば，一次覆工の岩盤側で集水し て，地下水を有効利用する方向に進んでいってほ しい。

神奈川県秦野市の上流に位置する NEXCO 中日 本が工事中の羽根トンネル工事では, 秦野市内の トンネル区間でトンネル内に湧水してくる地下水 を，秦野市に返水して秦野市が有効利用する約束 で工事を進行している。

排水構造でトンネル掘削が許される所では, ト ンネル掘削は, 水平方向の水源探査と考えて, 水 穂の国の日本の地下水を大切に有効利用してほし w。

\section{4 排水構造トンネルエ事によるトンネル上 部の地下水位低下範囲の予測}

\section{（1）高橋の方法}

高橋の提案したトンネル上部の地下水位の低 下範囲 $R(m)$ の予測方法は次式である（高橋, 1963)。

$$
\mathrm{R}=\sqrt{\frac{6 k H t}{n_{e}}}
$$

ここで $k$ は地山の透水係数 $(\mathrm{m} / \mathrm{s}), H$ はトン ネル底部から平衡地下水位までの高さ $(m), n_{e}$ は地山の有効間隙率, $t$ はトンネル掘削後の時間 (s) である。この式では, 降雨浸透流量は零と仮 定している。すなわち, 最も危険な状態での地下 水位の低下範囲を予測していると考えられる。し かし，(1）式の適用にあたって $n_{e}$ をどのように 選定すれば良いのか， $t$ をどのように定めれば良 いのかの課題があるが，我国では広く利用されて いる方法である。

\section{（2）Bear の方法}

Bearは, 開渠の周囲の地盤内での地下水の浸 透挙動として, Dupuitの式に降雨浸透を関連付 けて（2）式を提案している（Bear, 1972）。

$$
R_{\infty}=\frac{1}{\sqrt{2}}\left(\frac{k}{q}\right)^{1 / 2} \cdot H_{o}\left[1-\left(\frac{h_{o}}{H_{o}}\right)\right]^{1 / 2}
$$

ここで， $R_{\infty}$ は定常状態での影響圈， $q$ は地中に 浸透する平均的な単位面積あたりの降雨流量 $(\mathrm{m} /$ s), $H_{o}$ は不透水層からの地下水位の高さ, $h_{0}$ は 不透水層からトンネルまでの高さである（図2-1 参照)。(2) 式では降雨流量も考慮した所が高橋 の方法より現実的であると考えられる。この評価 手法は畑地の排水ドレーンの排水溝のピッチの設 計に適用されている。

\section{（3）大島の方法}

大島は数值解析を用いて，水収支理論に基づく 手法で影響圈半径の推定方法を提案している（大 島ほか, 1979 ; 大島, 1983)。この方法は現場に

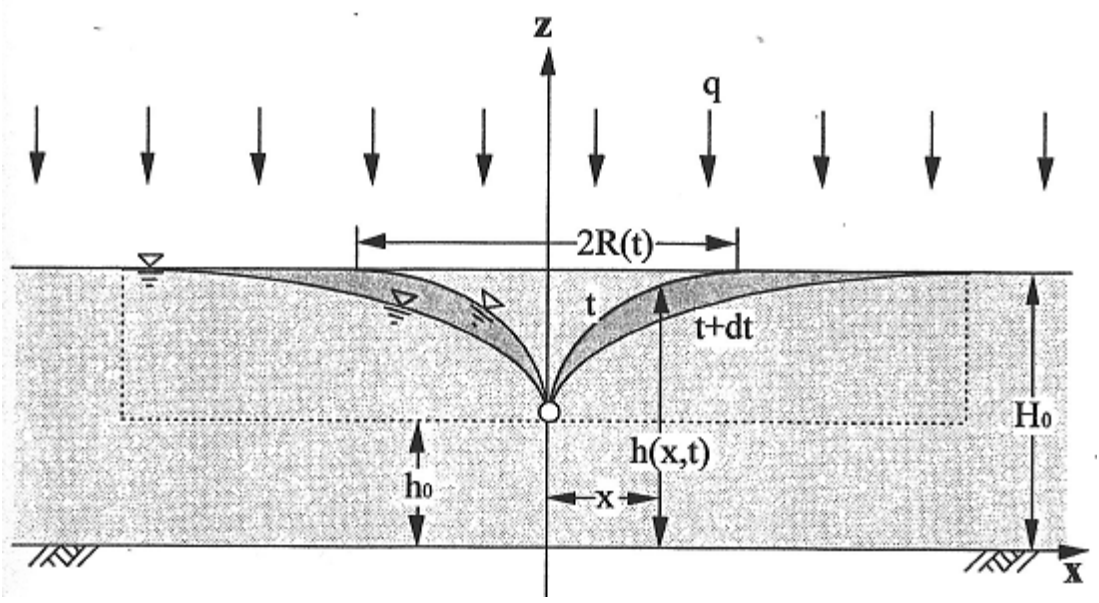

図 2-1＼cjkstart降雨を考慮した影響圏 
則した手法で, 気象データ (降雨流量, 蒸発散量 等）や地形，地質データなどがある時は，非常に 有効な手法である。特に近年では, 山全体をレー ザープロファイラー（L）で調査すると斜面の形 状が確認でき, 地表面の 3 次元モデル化は容易に なっている。今後は, 地山内の岩盤等の透水係数 の分布や, 現状の地下水位の分布をどのように調 査するかが課題である。

\section{(4) 西垣らの方法}

近年は, 山岳地帯であっても公的機関の降水 データの入手が可能になって来ていることを踏ま え, 筆者らは降雨浸透を考慮した有限要素法によ る鉛直断面 2 次元定常浸透流解析を用いて, 多く のパラメータスタディを実行し，平均降雨に対す る無次元量 $(\mathrm{q} / \mathrm{k})$ によって影響圈半径を推定す る手法を提案している（西垣ほか, 2004）。すな わち, Bearの提案した水平方向だけの Dupuitの 式に降雨浸透を関連付けた（2）式を基に，鉛直 方向の浸透を考慮した影響圈半径を推定する（3） 式を提案した。また，モデルや条件を変えた 300 種類の数值解析を実施して, この式の妥当性を検 証している。

$$
\mathrm{R}=1.22\left[\left(\frac{k}{q}\right)^{1 / 2}-1\right] \cdot H_{o}\left[1-\left(\frac{h_{o}}{H_{o}}\right)^{2}\right]
$$

一般に, 自然界では, 数值解析の境界条件のよ うな不透水層は存在しないため, 対象とする帯水 層の下部にどの程度の浸透性を持つ層が存在する かについても検討した。その結果, 対象層の透水 係数の半分以下の透水係数の層があれば，そこま でを带水層として考慮すれば（3）式を用いて影 響圈半径が推定できることも示した。

さらに，単位奥行 $(1 \mathrm{~m})$ あたりの幅からトン ネルへ湧水する流量 $\left(\mathrm{Qm}^{3} / \mathrm{s}\right)$ は (4) 式より推 定できることを示している。

$$
\mathrm{Q}=0.72\left(k / H_{\mathrm{o}}\right) \cdot\left(H_{\mathrm{o}}^{2}-h_{\mathrm{o}}^{2}\right) \cdot(q / k)^{0.35}
$$

一般にトンネルへの湧水流量を検討する際に は, 対象としている山の谷から谷までを境界条件 とするが，尾根を不透水境界として，トンネルの 深度が深い場合にはモデルをさらに拡げるため境 界の尾根を変更する手法の方が妥当であることも
提案している。

しかし，ここで示している方法は，あくまで帯 水層を対象としており，3 次元的な断層があるよ うな亀裂性岩盤内のトンネル掘削による影響圈半 径の予測やトンネル内への湧水流量の予測までは まだ検討していない。

ボーリング調査によって, ボーリング孔内の亀 裂の密度, 亀裂幅の分布, 亀裂の方向の計測は, 今日ではボアホールカメラによって可能になって いるが，亀裂の長さ（亀裂を楕円と仮定した時の 長径, 短径の長さ）までの推定は困難である。現 状においてトンネルを掘削する場の調査データが 欠落しているのは事実である。この亀裂の広がり の分布を地上から調査する手法の確立は, 今後の 大きな課題である。ボーリング調査孔でフロー メーター検層を行うことにより, ボーリング孔内 の各亀裂からどの程度の流量の地下水が流出して くるかを, 孔内の流速の変化を高精度の電磁流量 計等で計測していくと（西垣ほか, 2018 ; 西垣ほ か, 2020), 各亀裂面の広がりも予測できる可能 性がある。

これらのデータを用いて, 現実の場を対象とし てすべてを亀裂モデルで解析することは, 並列処 理がいくら進歩しても現有のコンピュータでは難 しいように思われる。最近開発されようとしてい る量子コンピュータを用いると, $1 \mathrm{~km}^{3}$ の亀裂性 岩盤内の地下水流動予測解析が可能になると考え ている。このような予測解析手法は, 排水構造を もつ亀裂性岩盤内の地下水挙動の予測だけでな く，そこでセメント系材料を注入して非排水構造 (water-tight 構造) にした場合のグラウト材の注 入範囲やグラウト材の注入工法の効果の確認のた めにも，重要な評価手法であると考えられる。

\section{5 トンネル直上付近の地盤陷没と地下水}

地表の陥没事象には, 地下中の空洞が関係して いることが多い。カルスト地形のドリーネへ地中 の土砂が徐々に流亡して, ある時, 大規模な陥没 障害が生じることがある。中国南部のカルスト地 区では，村一つが陥没した事象が生じている。 オーストラリア中部のカルスト地区では, 陥没し た中にホテルができ, 観光客が周囲の鍾乳洞を数 日かけて見学している所もある。 
空気中の $\mathrm{CO}_{2}$ を含んだ地下水が石灰岩を溶解し た空洞であるから，地表の土砂がその中に流亡す るのは当たり前かもしれないが, 人工の地下構造 物（トンネル）の直上の地盤が陥没する現象も生 じている。

2016年11月 8 日, 博多駅前の地下鉄工事中に大 規模陥没が起きた（谷川，2019）。45年前になる が, この地区にある中洲の地下鉄駅の掘削工事で は, 地下水低下工法を採用して, 掘削底部の揚圧 力を制御した。都市部のトンネル工事は, 前述し たようにシールド工法が主であるが，掘削断面が 異なるために, 地下水面下で都市型 NATM 工法 を実施した（三谷，2019）ことが陥没の原因と考 えられる。

既設の地下構造物への地下水の流入と同時に地 盤内の細粒土が構造物内に流亡して, その上部に 空洞が形成される。この空洞は地下水位が上下す る毎に成長していき, 地下構造物の損傷領域の直 上に陷没事象が生じる。下水道管の老朽化が原因 となってのこの事象の報告があるが（深谷ほか, 2019), 地表面からの物理探査では地表面から梁 度 $2 \mathrm{~m}$ 程度が探査の限界であり, 下水管の直近で 生じている空洞を探査するには至っていない。ま た，下水管の中から下水管の損傷部を探知するた めに, 孔内調查カメラの挿入試験や孔内探査口 ボットの開発も進んでいるが, 下水管の長大な全 長の調査には，これからも長い時間が掛かりそう である。家庭にある「お掃除ロボット」にカメラ を付けた装置や，電波が届かなくても「自走式の 小型ドローン」(ノルウェーですでに2016年に開 発されている）など，下水管内を探査させるよう な新しい調査機器の適用を待つ必要がある。さら に, このような装置を用いて, 地下の下水管内と 地表との間でのクロスホール探査を行い，地盤内 の 3 次元的な地層構造と空洞状況を探査する手法 を開発する必要がある。

水力発電用の導水路トンネル直上における陥没 事象も, 導水路トンネルの老朽化と地表の土地開 発等によって社会的な問題になる。このような事 象に対しては, 年間の降雨パターンの変化も大き く関係している。年間の総降雨量はあまり変わっ ていないが, 集中豪雨と渇水という極端な雨の降 り方の変化によって, 地下水位の高低差が大きく
なる。この地下水位差の拡大によって, 地下構造 物方向への地下水の浸透圧が大きくなっていき, 地盤の細粒土が地下構造物内へ流亡する現象が加 速すると, 地盤陥没事象は一層増えてくると考え られる。

このような現象に対して, 次の調査と対策が重 要である。

・地盤陥没は, 著者の経験では, 地下水位の変動 差が大きい所で多く発生している。したがっ て, 地中構造物に沿って地下水位の長期変動を 調査する観測井を設置する。その時に, 地下構 造物直上の埋め戻し材の粒度分布も調査する。

- 調查の結果, 地下水位変動差の大きい所に対 し, その付近にある下水道管の漏水箇所の修復 を重点的に実施する。また，地盤陥没を防ぐた めに, 地盤の骨格を構成している粒径の土粒子 （例えば $D_{85}$ 以上の粒子）を，地下構造物内へ 流亡させないようにして地下水を排水する。

既設の地中構造物に対して, 地下水圧は構造物 の劣化を進行させる。また, 地下水位が变動する から陥没事象が生じやすくなるので, 可能な限り 地下水位を低く一定にするために, 損傷箇所の止 水をしないようにする。土粒子を流亡させずかつ 止水はせず水を流す方法となると, 地中構造物内 から地山の土粒子を流亡させないフィルター付き の排水管を地山に挿入する方法が最も有効である が, それが無理なら, 地表から下水道管にフィル ター付きの排水管を設置して, 地下水位が低い状 態で排水できる対策を講じる等の技術を開発する ことが今の課題である。

\section{6 排水構造トンネルに関してのその他の例 （1）南阪奈道路・竹内トンネル（延長 $2.9 \mathrm{~km}$, 2004年開通)}

大阪府南河内郡太子町と奈良県葛城市を結ぶ竹 内街道沿の高速道路の建設では，このトンネルが 二上山の南麓に位置するため, 二上山からの湧水 があるのではと心配して地下水位を計測した。二 上山は, マグマ沸騰現象によるサヌカイト溶岩を 含むような火成岩であり, 山体内の透水性が高い ために，地下水位はほとんど水平であった。この 水位ではトンネル掘削によるトンネル内への湧水 はあまり心配する事はなかった。 
ただ，トンネルの西側坑口近くの「古代池」周 辺で,「万葉朝会」の方々が毎月決まった日に朝 がゆの会を実施している。池から $100 \mathrm{~m}$ も離れて いない所にトンネルを掘削することによって, 古 代池が枯渇する懸念が出てきた。

地山は透水性が良いのに, なぜ池が存続してい るかを考えた。池の底に底泥が厚く堆積して保水 しているからと考え，トンネルの掘削を実施し た。トンネル掘削によってトンネル周囲の地下水 は低下しても，池の水位は変化しなかった。この ような池の水位を保持するには, 池の周囲にダム 基礎の止水グラウトを設置するか, 古池の底部を ラバーで止水する必要がある。もっとも, トンネ ル工事の沿線に養魚場の池があったが, その池も 枯渴しなかった。これは本当に幸運だったとしか 言いようのない事例であった。

\section{（2）京都高速道路・新十条トンネル（稲荷山トン ネル延長区間2.5km，2007年完成）}

京都の伏見稲荷大社の北側山科にある稲荷山卜 ンネル工事では, 東側はNATM 工法で, 西側の 鳥羽街道近くの市街地の下はシールド工法で, 4 車線のトンネル（約 $350 \mathrm{~m} ）$ を掘削している。区 間が短いので，シールド機で西側から掘削して， 稲荷山の山麓で Uターンさせて掘削した。東側 の稲荷山は信仰の山で, 修行の場であるため, 地 表の小さな滝や水環境を守ることが課題であっ た。しかし，トンネル掘削工事では, 地下水に対 する対策は行わなかった。たた，近接している神 社の池が涸れる恐れがあるため, 池とトンネルが 連結していると考えられる断層には，あらかじめ 止水対策をして，池の水への影響を回避した。
このトンネル直上は, 西側の東福寺の境内を貫 流する三ツ橋川の源流である。偃月橋, 通天橋, 臥雲橋の三橋が架かっている名のある川であり, この川のせせらぎの音と東福寺の紅葉の組み合わ せは最高の古都の趣を成している。トンネル工事 の影響で川の流量が減少したため, トンネル湧水 を流入させ，川も三面張りにしている。余談にな るが,この三ツ橋川は, 明治に建設された琵琶湖 疎水の河床下をトンネルで流れている。当然, 同 じように直交する京阪線, JR 線の鉄道の下を流 れて鴨川に合流している。トンネルの中を流れる 川の建設で, 上の構造物は大丈夫であったかどう か問題であると思うが，まだ調査はしていないの で良くわからない。

\section{3. 非排水構造のトンネル施工}

\section{1 非排水構造トンネル（ウォータータイト (water-tight) 構造)}

排水構造のトンネル工事では, トンネルの掘 削工事に際してトンネル周囲の地下水位（水圧） を低下させてしまうために，表2-3に示すような 様々な問題が生じる。このような現状に対して, 地下水をトンネル内に排水させない工法が検討さ れるようになってきた。

表3-1に非排水構造トンネルの代表的な例を示 す。

\section{（1）シールド工法}

非排水構造のトンネル掘削工事で, 一般的に良 く用いられている工法にシールド工法がある。こ の工法は, 地下水面より下の地盤内を掘削する時

\section{表 3-1 非排水構造トンネルの代表的な例}

（1）シールド工法 (Shield Tunneling method)

(a) セグメント工法

（b）場所打ちコンクリートライニング工法

Extruded Concrete Lining 工法 (ECL 工法)

（c）場所打ち支保システムを用いた NATM 工法（SENS 工法）

Shield Tunneling Method Extruded

Concrete Lining New Austrian Tunneling Method(NATM) System

(2) プレグラウト工法

(3) ポストグラウト工法

（4）河川水の迂回工法 
に，掘削している空間に地下水が浸入するのを遮 蔽するための円筒形に掘削した壁面に構成しなが ら掘削する工法である。

\section{(a) セグメント工法}

このシールド工法は, 都市部の地盤に対して一 般的な地下掘削工法として適用されている。地山 を止水し，地山からの土压と水圧に耐えるための 覆工として，工場で生産したセグメントを現場で 組み立てて工事を進めていく方法である。この工 法は土砂地山に対して施工されてきたが, 岩盤卜 ンネル掘削における止水のための岩盤シールド工 法として, 広島駅北側の二葉山トンネル掘削工事 に適用されており，2019年にも掘削工事が進めら れている。道路トンネルで直径が $14 \mathrm{~m}$ もある大 断面で掘削されている。

\section{（b） ECL 工法}

この工法は, 現地で短い鋼繊維を混入したセメ ントミルクを圧送して現場でライニングを構成す る方法で, 岡山市内での地下共同溝の建設でも適 用された工法である（浦野ほか, 2001）。0.6Ma 程度の地下水圧に耐えるライニング構成ができて いる。

\section{(c) SENS 工法}

この工法は，掘削した空洞を安定させるための 支保材として場所打ちコンクリートを設置し, そ の変形が収束したことを確認した後, 二次覆工を 構築してトンネルを完成させる工法である。この 工法は, 青森県の東北新幹線の三本木原トンネル 工事（2004～2007年）に適用されている（飯田ほ か, 2004)。また, 北海道新幹線でも適用される 予定である。

\section{（2）プレグラウトエ法}

トンネル掘削することによって地下水位を低下 させることが困難な山岳トンネルの所で，あらか じめ地山内に懸濁液であるセメントミルクや溶液 系の止水材を注入して, 地山の透水性を低下させ てその後トンネルを掘削する工法を，プレグラウ ト工法と称している。

トンネル掘削に対する湧水対策としてのプレグ ラウトによる止水対策は, 青函トンネルの施工が 日本では最初であったと考えられる。この時に, セメントミルクに水ガラスを混ぜた材料を用いて 止水対策がなされた（秋田ほか，2011）。グラウ
卜後30年の時間が過ぎても止水性を維持している と結論を出している。以下の $(\mathrm{a}) \sim(\mathrm{e})$ に, 様々 な課題に対してプレグラウト工法を実施した例を 紹介する。

\section{（a）倉敷国家石油ガス備蓄基地}

岡山県倉敷市水島の GL-150～180m にある水 封式で定温の LG の国家備蓄事業では, 花崗岩の 透水性が良い場所に対しては, 超微粒子セメント を用いて透水性を低下させて $600 \mathrm{~m}$ の備蓄トンネ ルを施工している。

この工事においては事前に, 亀裂幅がマイクロ 単位の岩盤に対して, CSG（コロイドシリカ系の グラウト材）を用いて対応するための室内試験を 実験している（Kobayashi et al., 2014）。この研究 は,グラウトミルクの広がり半径を理論的に予 測する手法（Gestafson and Stille 2005）に適用さ れており，その手法はスウェーデン Aso 島の地 下 $450 \mathrm{~m}$ の四つのトンネル工事において試験注入 を実施し，その効果を確認している（Stille et al., 2015)。

倉敷では注入材料に $10 \mu \mathrm{m}$ 以下の超微粒子七メ ントを用いているが，凝結時間を調整できる分散 剂を添加して注入している。注入効果は従来型の ルジオン試験によって確認している。

\section{（b）瑞浪市深地層研究所の施工}

(a) の技術の展開として, 日本原子力研究開発 機構の岐阜県瑞浪市の深地層研究所にある深度 $300 \mathrm{~m}$ の試験孔で, $3.5 \mathrm{Ma}$ の高水圧下における既 存トンネルでの止水対策（ポストグラウト工法） と, これからトンネルを掘削するため止水対策 （プレグラウト工法）に関する研究が実施され, 硬岩（トンネルの周囲の岩盤）であれば十分に, 湧水をトンネル掘削前に止水して，トンネル掘削 が可能になることが示されている（Kobayashi et al., 2012)。

また，動的注入工法の周波数を変えることで, 微細な亀裂や広い亀裂への注入をコントロールす ることによって, 超微粒子のセメント系だけでな くコロイドシリカ系の注入への有効性についても 検討している（Kobayashi et al., 2015）。

深地層研究施設（深さ500m）では, 将来, 高 レベル放射性廃棄物を地層処分する際の, 花崗岩 中に扮ける地下水の挙動を研究している。この施 
設 (Underground Research Laboratory: URL) で は，高水圧下で地層処分する空間を，50年近くい かに維持し，処分中の坑内湧水を止水することが 可能であるかの研究を実施してきた。その結果, 超微粒子セメントミルクとコロイドシリカ系材料 の注入で地下水を止水できることを実証している (小林ほか, 2014 ; Tsuji et al., 2014 ; 辻, 2015, 2016 ; 見掛ほか, 2018)。ここは2022年度までに 埋め戻され, その研究所の土地は瑞浪市に返還す る作業に入っている。

\section{（c）トンネル直上における水環境の保全工法}

首都圈中央連絡自動車道 (圈央道) の八王子城 跡トンネル（全長 $2380 \mathrm{~m}$ ，八王子市）工事では, その上部にある八王子城跡の古井戸（坎井）や屋 根部にある御主殿の滝を保全するため, 先進導坑 をシールド工法で掘削して, その内部からセメン トミルクを $1 \mathrm{~m}$ 間隔で $5 \mathrm{~m}$ 外側まで注入した後, 地山の透水係数を $5 \times 10^{-8} \mathrm{~m} / \mathrm{s}$ まで改良した。本 坑はリーミング TBM 工法で掘削して, 防水シー トと覆工コンクリートにより0.6〜 $1.25 \mathrm{Ma}$ の水圧 に耐える非排水部（全長 $1000 \mathrm{~m}$ ）を形成している （足立ほか，2007）。

圈央道の高尾山トンネルは, 全線「明治の森高 尾国定公園」に位置しており, 八王子城跡トンネ ルと同様, 琵琶滝等の地表面の水環境保全のた めに, 南側坑口から約 $500 \mathrm{~m}$ 区間の非排水工法で 施工した。施工は, 直径 $4.8 \mathrm{~m}$ の泥水加圧式岩盤 シールドで先進導坑を構築して, その導坑内から トンネル周囲 $5 \mathrm{~m}$ の範囲に超微粒子七メントミル クを注入して, 止水構造にした。そして, その内 部を NATM 工法で直径約 $12.6 \mathrm{~m}$ まで掘削して, 完全に止水するために RC セグメント覆工（厚さ $63 \mathrm{~cm})$ を構築後, セグメントと地山との間に裏 込め注入して，完全な止水工法で施工している (田村ほか, 2012)。

琵琶滝の流量は保全できたが, 近隣の稲荷祠の 湧水が何度も水涸れを起こしているとの話が出て いる。このようにほぼ完全な止水対策をしても, 小さな湧水が時々水涸れを実際に起こしているか どうかについては，工事後の効果確認として，正 規の機関による調査を数年間にわたって行う必要 があるかもしれない。

\section{（d）トンネル掘削による地表面変状の防止対策}

一般に, トンネル掘削による地表面の沈下は, トンネル掘削が地山内の地中応力を解放すること により, トンネルの天端が鉛直方向に沈下するた めに生じることが，主たる原因として考えられて いた（島田, 1980 ; 奥田ほか, 1999 ; 竹内ほか, 1999）。しかし, 近年, トンネル天端の鉛直方向 の変位よりも, 地表面の沈下が大きくなるような 事象に遭遇することがある。この現象は, トンネ ル掘削によって地下水位が低下し, それによって トンネル上部の地盤内の有効応力が増加し, 圧密 沈下現象が生じているものと考えられる。

このような自由水面が水位変動することによる 地盤沈下の解析手法は, Biotの 3 次元での有効応 力変化による基礎方程式（Biot, 1941）を，浸透 と変形をカップリングした数值解析による解析手 法に適用すべきであるが，このようなケースの実 際のモデルは数百万節点規模となり, 現状の計算 機の容量では 3 次元解析を容易に実行することは 困難である。

この現状に対して, 飽和領域において地盤の荷 重変化による 3 次元圧密を解析する手法は, 西垣 ら（2005）によって開発されている。この3 次元 の解析手法は, 関西新空港の 2 期埋立工事におけ る圧密沈下の予測解析に適用されている。

西垣らは, この飽和領域を対象とした解析手法 を，トンネル掘削による地下水位低下に対しての 飽和・不飽和領域を対象とした 3 次元の圧密沈 下解析コードへと拡張している (Nishigaki et al., 2008; 入江, 2006)。

この解析手法により, 花崗岩の風化土 (マサ土) が堆積している地盤に対する山岳トンネルの掘削 工事において, 深さ方向の複数深度で採集した供 試体に対する e-log 曲線と単位体積重量等の物理 特性を調査して, トンネル掘削に際して地下水位 をどこまで低下すると, どの程度の地表沈下が生 じるかの予測解析を実施した。

地下水位はトンネル天端の 20 ～30m 上方にあ り，トンネル掘削による地下水位低下を軽減する ために，長期的な劣化が極めて少ない溶液型活性 シリカ系注入材料を切羽断面の周囲に $2 \mathrm{~m}$ 厚まで 注入した。この当時 (2007年頃) は, 風化マサ土 に広範囲に注入する材料としては溶液型の注入材 
しかなく，この材料では強度的に問題があったた め, 掘削中は鋼管フォアパイリングで天端の沈下 を抑制した（中出ほか，2017；中出，2018）。

\section{（e）地表景観と作物環境の維持対策（富良野市 北の峰トンネル工事)}

セメント系の注入材は懸濁液であるため, 岩盤 のすべての亀裂内に注入することは困難であった が, 近年では $1 \sim 2 \mu \mathrm{m}$ の極超微粒子セメントミ ルクを注入して地山の力学的強度を増加させ, 同 時に地山の透水性を低下させる工法が開発された (西垣ほか, 2011)。

北海道富良野市, 旭川十勝道路の北の峰トンネ ル工事 (約 $2.9 \mathrm{~km})$ において, 地表の水環境を守 るために, トンネル上部とトンネル内部の先方に 極超微粒子七メントミルクを注入し, ウォーター タイト構造の対策（550m 区間）を実施した報告 がなされている（坂巻ほか, 2013 ; 伊達ほか, 2014）。トンネル掘削しようとする地層内で, ト ンネルの上部が極超微粒子等によるグラウト材で 十分に充填されているかを確認するために, トン ネル坑内と地上との間で弾性波速度によるトン ネルトモグラフィ探査をしている（山本ほか, 2016 ; 成田, 2017 ; 小林ほか, 2015a ; 小林ほか, 2015b ; 斎藤ほか, 2014)。これは, 新しい技術 を適用して地面の水環境を守った事例である。

\section{(3) ポストグラウト工法}

\section{(a) ポストグラウトの考え方}

地盤や山体中の地下水の状況を完全に把握する ことが困難であり，トンネル掘削中に湧水に遭遇 することは多い。このような湧水も, 山岳トンネ ルでは経時的に減水することが多いため, 過去の トンネル掘削では湧水が減水するまで待って工事 を再開するという施工を実施していた。寒冷地で は，冬に地下水が凍結している間に掘削したよう な例もある。

しかし，湧水が工事を再開できる程度まで減水 しない場合には，トンネル掘削工事を中止する か, トンネルのルートを変更する等の検討が必要 となってくる。実際に掘削を放棄し，ルートを変 えた例がある。本来なら，この湧水が地表面の生 態系や水文環境に影響を与えていると考え，その 調査を優先して実施すべきであるが，かつては， いかにトンネル工事を無事に遂行するのかが最優
先であった。

トンネル工事では, 地下水が一番怖い相手であ る。過去のトンネル工事では, $1 \mathrm{~km} に 1$ 人の死 者が坑内事故で出るのが普通であった。現在で は, 先行探査水平ボーリング等を実施して, 切 羽の前方探査をするようになってきたが，過去に は, 地表からの物理探査や地質調査によって想定 していた地山の断層面の位置がずれていて, 掘削 中に湧水により切羽が崩壊して死者が出たりして いた。このようにトンネル工事は, 地下水がある かないかで危険性が異なると言われていた。

掘削する山の木が松か杉かで, トンネル工事の 難易度は変わるとも言われている。杉や桧の山に は地下水が十分にあり, 松の木の山には地下水が あまり無いとも言われている。実際, 岡山県東部 の松の木の山でトンネルを掘削した際に, 湧水が なかった経験がある。

トンネル掘削中に湧水が出現してくると, 水の 浸透がトンネル方向に集中するため, 浸透する方 向に新たに浸透水圧が作用してくる。一般にトン ネルの上部からの全応力は土圧と静水圧だけを長 い間考慮してきたが，トンネル内に湧水が発生す ると，その方向に 3 次元的に浸透水圧が作用する ため, 切羽面は一層不安定になる。

このような場合には，一時的にトンネル内に $5 \mathrm{~m}$ 程度の止水壁を設置して, トンネル周囲の地 下水流動を一時的に静止させた後, 掘削したトン ネルの周囲に止水材を注入して, 湧水対策をす る。

トンネル内に止水壁が構築できない場合には, トンネルの周囲に仮の止水材を注入して, 地下水 の湧出による地山内の地下水の浸透速度を一時的 に抑えてから，ゆっくりとセメントミルク系の材 料を注入して, 湧水を速やかに止水する必要があ る。さらに，湧水してきた地下水がヒ素等の污染 物質を含んでいると，この湧水を放流した下流の 河川水が飲用水として利用できなくなることがあ る。このような状況に対応するには, トンネル内 への湧水流量を低下させるためのポストグラウト 工法が適用されることがある。しかし，ポストグ ラウト工法を実施すると, グラウトした背面の地 下水位が上昇するため, グラウト範囲外の水圧に 対して, グラウトした範囲の地山や覆工がその水 
圧に本当に耐えられるかを，どのように評価して 設計するかが課題である。

ここでは，掘削していたトンネル内でヒ素を多 量に含んだ湧水が生じたために，その湧水流量を 減水するためにポストグラウト工法を実施した例 を以下に紹介する。

\section{（b）北薩トンネルにおける污染湧水の減水対策}

鹿児島県北部の北薩トンネルは2018年 3 月に開 通した。出水市と鹿児島空港を結ぶ県管理の高 規格道路で, 出水山地を貫く最大土被り約 $370 \mathrm{~m}$ の全長 $4850 \mathrm{~m}$ の長大トンネルである。掘削中に 最大 $20 \mathrm{~m}^{3} /$ 分の湧水に見舞われ, トンネル貫通 後も恒常的に約 $10 \mathrm{~m}^{3}$ / 分の湧水が発生した。こ の湧水のうち出水市側の坑口から1500 2200m 間で, $\quad 0.1 \sim 0.3 \mathrm{mg} / \mathrm{L}$ の高濃度のヒ素を含有する ことが確認された（木佐貫ほか, 2015 ; 大山ほ か，2017）。公共用水域に打ける水質污濁に係る 環境基準に基づき, 排出先河川でのヒ素濃度は $0.01 \mathrm{mg} / \mathrm{L}$ 以下にする必要がある。

このような污染水の対策として, JOGMECで は全国の旧鉱山からの污染水を水質処理によって 対応している。しかし，現状でいつまでこのよう な水質処理を継続しなければならないのかは, 大 きな社会問題になっており, その解決策がない状 況である。

污染水の処理として, 污染水は自然から湧出し てきたものだから自然に返せばいいと考えて, 注 入する井戸を設置しての注入試験も実施された が，すぐに下流の川へ污染水が流出してきたため に，この対策は中止になった。また，そもそも一 度湧出してしまった污染水を地盤内に注入するこ とは許されないと考えられる。

トンネル掘削により湧水してきた污染水の処理 を考える時に，公的構造物の供用年数間（約50 年）を想定して，50年間だけ污染水を処理すれば 良いと考えるのは誤りである。鉱山からの湧水処 理のように, 何百年間あるいは未来永劫に処理す る必要が出てくる。このように考えると, トンネ ル掘削する際には，重金属で山体が污染されてい ないか, 污染された地下水が存在するかどうかを 事前に調査で把握することが, いかに大切かが分 かる。

上記の観点より北薩トンネルでは, トンネル内
への湧水の内, 污染濃度の高い区間を止水する 事にした。止水工法の詳細は多くの論文で発表 されている（古田島ほか, 2017a ; 古田島ほか, 2017b；中出ほか, 2019）のでここでは割愛する が，以下の技術の発達が関与していると考えられ る。

・亀裂性岩盤に対して, 止水と強度向上を兼ねた $1 \sim 2 \mu \mathrm{m}$ の極超微粒子セメントが開発された (西垣ほか, 2011)。

・そのグラウト材を用いて, 日田の大山ダムにお ける止水(カーテングラウト)技術開発がされ, 実際に確実に止水できる実績が確立された（前 田ほか, 2014 ; 古田島ほか, 2017a ; 古田島ほ か, 2017b)。

・トンネル内への湧水を止水することによるトン ネルの安定解析手法（浸透と変形を考慮した カップリング解析手法) を実際のフィールドに 適用した（中出ほか, 2019）。

地下水位が $130 \mathrm{~m}$ 程度まで回復した後もトンネ ルの変形を計測したが、ほぼ零であった。これは 地山が花崗岩であり, 強度が十分にあったためで ある。

\section{（4）河川水の迂回工法}

\section{（a）中国自動車道・大万木トンネル}

中国自動車道・尾道松江線の三次市北部にある 高野 I.C. から吉田掛合 I.C. の間に位置する大万 木トンネル（全長4878m）工事では, 低土被りの 和南原川の下部を掘削する事により，河川の下流 での農業用水を減少させる懸念があった（新宅ほ か, 2012 ; 狩野ほか, 2012)。また, 当該地区で は井戸や湧水を利用している事から，影響区間の トンネルを非排水構造として施工した。覆工は円 形で, 最小厚で $500 \mathrm{~mm}$ 厚の設計をして, 土圧と 水圧に耐える構造とした。

河床下を掘削するために河川上流に堰を設置し て, 和南原川の水をバイパスで掘削区間下流に流 下する対策をした。この対策により，工事中は河 川からの漏水を排水することなく, ドライワーク でNATM 工法掘削工事を実施した。課題は, ト ンネルの非排水領域区間をどこまでに設定するか である。本工事では, 理論上の非排水区間を決定 したが, 地山の透水係数が低かったため, 地山内 にグラウト注入を実施しないで, 非排水区間とし 
て成立させることができた。2010年から工事に入 り2012年に完了している。和南原川の堰を取り外 した後, 地下水位も回復し, トンネル天端より $10 \mathrm{~m}$ 以上まで急速に回復した。

ただ，河川周囲は非排水構造になっているが, 山岳地は排水構造であるため, 和南原川に流入す る小川の流量減少が生じた。山全体の環境を保全 するには，トンネル全域を非排水構造で設計する 必要が生じる。また, 地下水位がトンネル天端よ り 40m 以上になると, 現状の覆工では水圧に耐 えられない事になってしまう。このような課題は 今後の大きな研究テーマである。

\section{(b) 新名神高速道路・箕面トンネル}

大阪府北部の神戸 JCT から大津 JCT まで, 新 名神高速道路の建設がなされている。この工事の 大阪府域の西側区間（神戸〜高梘，21.2km）に， 土被り約 $19 \mathrm{~m}$ で勝尾寺川と交差する工区（箕面 トンネル東工事区）がある。この勝尾寺川の流域 保全と周囲の水環境保全対策として, 大万木トン ネルと同じような対策を実施した（伊藤ほか, 2013 ; 岡ほか, 2016)。すなわち, 以下の手順で 工事を進めた。

(i) 勝尾寺川に対しては, トンネル掘削によって 地下水位に影響する範囲外で「河川水の切り 廻し」を実施し，河川には底板コンクリート を設置して河川水を地下に引き込まない構造 でトンネルを掘削した。

(ii) 非排水構造ではないトンネル区間の湧水は, 横坑より導水して勝尾寺川に返水した。

(iii）トンネルは, 河川に影響がある区間は非排 水構造で構築した。すなわち, 覆工コンク リート厚は $90 \mathrm{~cm}$, 覆工コンクリート強度は $30 \mathrm{~N} / \mathrm{mm}^{2}$ で円形である。

(iv) ここで課題になるのは, 非排水構造の区間を どこまでに設定するかであるが, 現場の地山 の透水係数を計測して区間を決定した。

（v）非排水構造区間の端部には，高さ $5 \mathrm{~m}$ で幅約 $12 \mathrm{~m}$ のファンカーテングラウトを実施して 止水した。

（vi）非排水構造区間の検証方法として $1000 \mathrm{~m}$ 級 の超長尺先進ボーリング孔を掘削して, 水理 地質情報を確認した。

(vii) 深度の異なる観測井を複数設置して, 工事
前, 工事中, 工事後の地下水位の変動を計測 して, 地下水位のモニタリングを実施して, そのデータを公開してきた。当然, 河川の流 量変化も計測して, 工事の妥当性を検証して いる。

高槻〜神戸間は2018年 6 月に開通して, 勝尾寺 川の流量は保全できた。

\section{（5）トンネル施工によるその他の課題 （a）止水材料の課題}

トンネル掘削による地下水や地表の水環境問題 への影響について論述してきた。また, それに対 しての悪い影響については, トンネル掘削をして も, 山体の地下水環境に対して影響を最小限にす る工法で施工した例を示した。

都市部の下は, 現状ではシールド工法でほとん どを掘削しているが, 建設コストが高いために, これからもこの方法が継続して適用できるのかの 疑問がある。

掘削することによって地下水が湧出してくる砂 質地盤に対しては, 極超微粒子セメントミルク材 を注入することによって地山の止水性と強度を増 加させることが可能になっているが, このような 特殊セメントは材料費が高価である。このような 材料に変わるもっと安価な止水材料を開発してい く必要がある。

止水注入材の注入は, 注入材の粘性が高いと 注入圧が高くなる。注入圧に対しては, 1〜 $5 \mu \mathrm{m}$ のベントナイトと $2 \%$ 程度の海水やエ夕 ノールとのスラリーは低粘性であるため, 亀裂性 岩盤に低圧力で注入して, その後, 周囲の真水で 注入材中の塩分濃度が低下してくると, 止水性が 上昇してくることについても研究した（西垣ほ か, 2004）。この方法は, 低レベル放射性廃棄物 の地層処分における掘削損傷領域の透水係数を低 下させる手法として適用した。この材料は，止水 はするが地山の強度を上昇させないので, 掘削時 は地山の強度を覆工で支えなければならないた め, 強度のある支保工が必要となってくる。

また，粘土地盤に対しては，多量の湧水はない が, 地下水が低下すると地山が圧密変形をするの で，十分な止水が必要である。

\section{（b）地山の前方探査技術}

地山を止水する場合には, 地山の状況を掘削前 
に事前調査で探査しておく必要がある（土木学 会, 2007 ; 亀村ほか, 2018)。超長尺先進ボーリ ングによる穿孔振動探査技術で切羽前方の地山内 の地下水状況を高精度に把握する技術を適用し て，この技術の可能性を探究する技術も開発され ようとしている。

しかし，これらは地山をトンネル掘削するため の地山等級調査であって, 地下水に関する調査で はない。地上からの調査では難しい地下水に対し ては, 切羽前方の調査として複数の水平ボーリン グ孔を実施して，調査していく必要がある。川端 らは，このような考え方から実際のトンネル掘削 工事に扔いて, 流量変化, 水圧変化から切羽前方 の地下水を探査する方法について論述している (川端ほか，2018）。

地山の地下水が豊富にある所では, 既存の $\phi 66$ のボーリング孔では十分な排水が不可能であるた め, 調査とは言え $\phi 86$ 以上の孔径で掘削すること も有効である。また，この排水孔を用いた複数孔 間の水圧クロスホール試験を実施して, 地山の透 水性を調査して, 止水対策を検討する必要があ る。

また，ボーリング孔やボアホールカメラの情報 など，止水のための注入材料を選定できる情報を 収集してから，注入材を判定してほしい。

\section{4. 海外での課題}

日本と同様に海外でのトンネル工事が進んでい る。排水システムは, トンネルへの水圧を減圧で きて良いが, 地下水に含まれているカルシウムの 沈積によって, 目詰まりが生じる。目詰まりを取 り除くことはきわめて高価な業務であることか ら, 非排水構造のトンネル工法を実施している (Lemke et al., 2006)。

プラスチックの止水メンブレンとジオテキスタ イルを組み合わせて，メンブレンを保護しなが ら, トンネルの地山からの湧水を止水する工法の 紹介がある。

長期間の維持管理費を削減するために，二重の 止水メンブレンを用いてその耐久性を検討して, 100年以上の耐久性のあるメンブレンがあること を示している (Meissner, 2013)。しかし, 結果と
して地山の地下水を保全していることにもなって いる。

伝統的な米国の非排水構造とヨーロッパの国々 の非排水構造を比較して, 米国の方が全体的に堅 固な非排水概念で実施されていると評価している (Aram, 2016)。しかし，これらの非排水構造は, トンネルの中に地下水が流出して来ない事に対し ての構造であり, 山体中の地下水を守るという考 え方の非排水構造とは異なる概念である。

中国武漢の揚子江の下に, 泥水シールド 4 車線 の道路が建設された事例が紹介されている (Wang et al., 2007)。河川下のトンネル工事は, 我国で も多くなされているが, これも, 地下水の環境を 考えてのトンネル工事とは言えない。

ノルウェーの首都オスロの地下において TBM シールドトンネル掘削工事が検討された。事前 止水のためのグラウト工法がなされ，TBM で掘 削し，セグメントを設置する工法がなされてい る (Dammyr, 2017)。この場合も, トンネル掘削 中の地下水の湧水を少なくすることが主たる目的 で, 地山の環境を検討してのトンネル掘削工法と は考えていないようである。

\section{5.おわりに}

\section{1 結論}

世界には情報が多くて，これを全て網羅するの は極めて困難である。トンネル掘削の際の湧水対 策は, 日本だけではない。しかし, この課題はト ンネル工学分野の中で研究発表されているため, 地下水分野の研究者にはあまり目につかないこと が多い。トンネルを掘削する立場としての仕事が 多いので，なんとか安全にトンネルを掘削できな いかと考えてしまう。トンネル掘削は自然の体に 穴をあける事である。したがって，色々なことが 起こって当然であるが, その被害を最小にするこ とが工学であると考えている。

また，日本のトンネルと地下水で考えた技術 を，インドネシアやシンガポールやマレーシア等 に拡張していくことも可能ではないかと考えてい る。日本の隣の台湾でも, 台北地下鉄環状線の現 場において台湾の技術者育成の取り組みを行って いる（山本，2019）。著者の経験で，台湾の雪山 
トンネルが開通した直後, このトンネルの地下水 対策の評価を現地でさせていただいた。トンネル 直上にある雪山の茶畑の地下水位は低下したが,

トンネル内の周辺の岩盤の間隙水圧も零であっ た。本当に十分な排水がトンネルの下でなされて いた。しかし, 現在は, 地下水が十分に排水され ていると言っても，排水施設は永久構造物ではな いため，それが目詰まりした時に何か起こるか分 からないことから，常にモニタリングする必要が ある事を指摘させていただいた。

日本の交通システムのトンネルとしては, リニ ア新幹線のトンネル工事が, 今後の主たる課題に なると考えられる。

\section{2 今後のトンネル工学の課題 （1）亀裂性岩盤内の地下水モデルの確立}

現在では, 堆積層内のトンネル掘削において調 查・解析費が十分にあれば, 地下水調査やその対 策はある程度まで可能になってきている。しか し, 山岳トンネル等の工事では, 亀裂性岩盤内の 水理特性に関する特性がまだまだ解明されていな いので, この分野の研究には多くの課題があり, 研究テーマが残っている。

たとえば，亀裂性岩盤内の亀裂幅の分布は, ボーリング孔内のボアホールカメラ調査によっ て，ある程度の把握が可能になってきている。こ のような地山に対してグラウチングをすると, ど の範囲までグラウト材が流動していくかについて の予測が良くわからない。

一般にグラウチングは, 濃度の薄い材料から 徐々に濃度を濃くしていくが, この注入工法で良 いのかどうかを，以前迷ったことがある。グラウ チング工の先人達がグラウト材の濃度を徐々に濃 くして注入する理由が，良く理解できなかった。 亀裂幅が大きい所は透水係数が大きいので，注入 孔内の注入圧により, 亀裂幅が広い龟裂ほど遠い 所まで注入でき，注入範囲が広くなると考えてい た。しかし, 室内実験で亀裂幅が異なるモデルで 実験すると, 亀裂幅が狭い亀裂の方が, 幅が大き い亀裂より遠くまで注入材が注入されることが分 かった（西垣・見掛，2002）。これによって，最 初に濃度の薄い材料で亀裂幅の狭い亀裂を広い範 囲で止水して, その後, 濃い材料で亀裂幅の広い
亀裂を止水されることがわかり, 先人達の注入方 が合理的であることがわかった。

このようなグラウト試験を, グラウト材の中に 発信機能を持ったマイクロチップを混入して実施 すると，電波が到達する範囲でその地山の亀裂の 情報を把握することが可能になる。医療分野では 人体内の小腸から大腸, 直腸までの内容がマイク ロチップ調査できる時代になっているので, この 技術を応用すると, 亀裂の 3 次元での情報が将来 は解明できるのではと考えられる。

\section{（2）トンネル劣化対策}

古代エジプトのトンネルは, 石でライニングを していた。イスラエルのエルサレム地下で40年前 に, 3000年前の水路トンネルの調査に行ったこと がある。ここも石のライニングであった。しか し，日本のトンネルはコンクリートが主体であ る。地山の環境によってその劣化は異なるが, い ずれ危険な状況になってくる。

そのトンネルをどのように修復するかに大きな 課題がある。セメントコンクリートの分野におい て「ジオポリマー」に関する研究が, 最近日本で も行われている。イタリアのコンクリートは1000 年以上経ってもまだ劣化はしていないと言われて いる。火山灰と石灰のコンクリート（セメントで はない) であるため，まだ固化が進行しているそ うだ。詳細はインターネット等で調べることがで きるので割愛する。日本人オリジナルの研究では ないが, この材料を用いて 3 次覆工をすると 1000 年以上は劣化しないトンネル修復が可能ではない かと考えている。トンネルを通る列車も自動車 も，いずれはもう少しコンパクトな形体になるの で，十分な修復スペースができると考えられる。

\section{（3）トンネル掘削工法の進化}

トンネル掘削技術も，現状の技術がもっと進歩 して，例えばTBM（トンネルボーリングマシン） が高速で回転して掘削して, 切羽の先端に $1200^{\circ} \mathrm{C}$ くらいの熱を持たせることで掘削したズリが陶器 のように硬くなって, 覆工の必要がないトンネル 掘削工法が開発される時代が来ると考えられる。 この考え方は, 故足立紀尚先生（謝辞参照）から 教えていただいた。しかし，まだ完成していな い。このような工法であれば, 容易に非排水構造 のトンネル掘削が可能になり, 自然災害の洪水か 
ら住民を守るための地下放水路が，日本中の河川 の下に掘削できると考えられる。

地上を高架で走って窒素ガスを出している道路 もすべて地下に建設でき, 地上は緑があふれる生 活空間に再創成できる日が来ると考えられる。

\section{（4）自然災害減災対策トンネルの建設}

異常気象が, 二酸化炭素等による地球温暖化で 起こっていると考えると, いつ火力発電やセメン 卜工事がなくなるかが分からないので, 異常気象 はこれからも続くと考えられる。このような状況 の中では, 土石流や斜面崩壊が世界中でいつまで も起こると考えられる。豪雨によって土砂竾害が 生じるような山体に対しては, 山体の中にトンネ ルを掘削して, 山体の地下水の浸透を地表面では なく地中方向に変えると, 地表面下の地下水によ る浸透水圧が山体のトンネル方向に作用するため に，土砂災害はある程度防止できると考えられ る。したがって，このようなトンネル工事が安価 で可能になると，これからは防災トンネル工事が 世界中で必要になってくる需要が高まってくると 考えられる。

もし，地球温暖化が100年程度で終焉するなら ば,このようなトンネル空間は100年後には必要 なくなり, 地域の住民の雨の日のスポーツセン ターや冷蔵庫に変わる食料貯蔵空間等に利用する ことが可能になると考えられる。

本論説では図面を使いませんでしたが, 地下水 学会の興味のある方々であれば, すべてネット検 索から文献や詳細な図を得ていただけると考えて いますので, 紙面の都合上割愛させていただきま した。諸氏にこの分野の新しい展開を期待して, 筆を置かせていただきます。

\section{謝 辞}

本報文の執筆にあたり，下記の方々から貴重な 助言と資料をいただきました。御所属と御氏名を 記させていただき謝意を表させていただきます。 清水建設（株）小林伸司氏, 中国電力（株）入 江彰氏, 応用地質（株）吉田真一氏, 鹿島建設 (株) 瀬尾昭治氏, (株)熊谷組 中出剛氏。また, 2019年 2 月10日に享年80歳で他界した, 故京都大
学名誉教授足立紀尚先生には，45年間の長きに渡 り，青函トンネル内の湧水の予測からリニア新幹 線の新しい課題までをご指導いただいたことを大 変感飶していることを記させていただきます。

\section{参考文献}

秋田勝次・井浦智実・朝倉俊弘 (2011) : 海底卜ンネル で施工されたセメントガラス注入材の長期材料特性 と性能の評価. 土木学会論文集 F1 (トンネル工学), 67 (2), 95-105.

足立賢一・千場 洋. 吉冨幸雄 - 野中良裕 (2007)：

山岳トンネルに扮ける高水圧ウォータータイトの施

工, 圈央道八王子城跡トンネル. トンネルと地下,

38 (11), 17-24.

飯田廣臣・磯谷篤実・井浦智実 · 川嶋潤二 - 小西真治

（2004）：シールドを用いた場所打ち支保システムの

施工. トンネル工学報告集, 14, 195-202.

伊藤哲男・宇根孝司・佐伯 徹 (2013)：トンネル掘削 に伴う地下水流動対策 - 新名神高速道路箕面トンネ ルー。・ネルと地下, 44 (9), 17-26.

入江 彰 (2006a)：トンネル掘削に抢ける地盤環境保 全に関する研究. 岡山大学大学院自然科学研究科博 士論文, $13-51$.

入江 彰 (2006b)：トンネル掘削における地盤環境保 全に関する研究. 岡山大学大学院自然科学研究科博 士論文, 92-130.

牛越 博 - 望月孝利 (1988): 二大構造線の湧水地帯を

貫く中央自動車道長野線塩尻トンネル. トンネルと 地下, 210, 15-24.

梅田雅弘・井戸澄夫 ·出口惊一・若林良二 (1997)：環 境保全対策を充分考慮した大規模都市型トンネルの 施工 京都地下鉄烏丸線延伸工事. トンネルと地下, 318, 25-33.

浦野真次・後藤 茂・栗田守朗（2001）：ECL工法に おける鋼繊維補強コンクリートの充てん性に関する 検討. 土木学会第56回年次学術講演会, V-138, 276277.

大島洋志 (1973)：毎分23t の異常湧水に挑む山陽新幹 線福岡東工区. トンネルと地下, 36, 12-21.

大島洋志他（1979）：トンネル工事を対象とした水文調 査法の研究. 鉄研報告, No.1108.

大島洋志 (1983)：トンネル掘削に伴う湧水とそれに伴 
う水収支变化に関する水文地質学的研究. 鉄研報告, No.1228.

大島洋志 (2002) : 私の地質学随想. 土木工学社, 4849.

大山洋一 · 木佐貫浄治 - 宮本裕二 · 臼本直仁 - 島田允 克・入佐純治・島田和彦 (2017)：トンネル掘削から 判明した紫尾山花崗岩体中の七素鉱物とその溶出機 構. 応用地質, 58 (4), 264-278.

岡 浩一 - 南場憲一郎 - 前本将志 - 小杉勝之 · 加藤宏征 藤本昭弘 ·近藤正隆 (2016) : 新名神高速道路箕面卜 ンネルに㧍ける水環境保全対策について. 地下水地 盤環境に関する研究協議会, 地下水 - 地盤環境に関 するお知らせ, 25, 1-11.

岡本利彦 (1976) : 新神戸トンネルの施工 土木編. トン ネルと地下, 183, 41-48.

奥田 庸・阿部敏夫 ·進士正人 (1999)：土被りの浅い 未固結地山トンネルの地表面沈下抑止方法に関する 評価. 土木学会論文集, No.637/VI-45, 79-92.

上山 満·前川 秀·神田清二 (2016) : 「安全·安心 · 快適」をめざして〜東京外環自動車道（松戸 IC 〜高 谷 JCT 間) の設計概要. 第21回地下空間シンポジウ 厶, 土木学会, B1-2.

狩野浩資 - 景山浩孝 ·安部 学 (2012) : 流域の水利用 への影響を考慮したトンネル構造一中国自動車尾道 松江線大万木トンネルー。トンルと地下, 43 (11), 13-19.

亀村勝美 - 倉橋稔幸 · 岡崎健治 ·山崎秀策 - 村上秀幸 丹羽廣海 (2018) : 先進ボーリングによる地山評価と その効果. トンネル工学報告集, 28, 1-28.

川端淳一・升元一彦・岩野圭太・岡田侑子 (2018)：卜 ンネル切羽前方地下水の新しい調査・評価手法につ いて. 地盤工学会誌, 66-2 (721), 22-25.

木佐貫浄治・宮本裕二 - 鈴木雅文・辰巳裕二（2015）：

自然由来の七素を含む大量湧水の減水対策試験 - 北 薩横断道路 北薩トンネル (出水工区) - . トンネルと 地下, 46（10）, 19-24.

串山純孝 -小林素一 (1975): 湧水と戦う立坑工事上 越新幹線中山トンネル. トンネルと地下, 58, 15-25. 古田島信義・鈴木雅文・中出 剛・木佐貫浄治 (2017)： ダムのグラウチング技術を適用した山岳トンネルの 試験グラウチング.ダム工学, 27 (3), 195-206. 古田島信義·鈴木雅文・中出 剛 - 片山政弘 - 手塚 仁 · 木佐貫浄治 (2017)：北薩トンネルにおけるヒ素を
含有するトンネル湧水の減水対策 -ダムのグラウチ ング技術を適用した山岳トンネルの岩盤グラウチン グー。地盤工学ジャーナル, 12 (4), 469-478.

小林 暁 - 齋藤宏樹 - 山本拓治 - 伊達健介 - 小泉 悠 成田 望・横田泰宏 (2015a)：ウォータータイトト ンネルに扔ける止水注入工の設計事例. 地盤工学会 関東支部, 薬液注入シンポジウム, 234-237.

小林 暁 - 齋藤宏樹 - 成田 望 - 横田泰宏 - 山本拓治 ·

伊達健介・小泉 悠 (2015b) : ウォータータイトト ンネルに扮ける止水注入工の三次元注入管理と効果 確認工. 地盤工学会関東支部, 薬液注入シンポジウ 么, 238-241.

小林伸司 - 宮嶋保幸 - 水道 健 - 金戸辰彦 - 山本浩志 · 前島俊雄（2014）：倉敷基地 LG 岩盤貯槽における高 水圧下のグラウト施工実績と改良効果の評価につい て. 第42回岩盤力学に関するシンポジウム講演集, 土 木学会, 125-130.

齋藤宏樹・成田 望・横田泰宏（2014）：ウォーター夕

イトトンネルの施行実績旭川十勝道路 富良野市北 の峰トンネル工事. 土木学会第69回年次学術講演会,

57-58.

坂巻俊次 - 柏谷光晴 - 齋藤宏樹 - 伊達健介 - 成田 望 （2013）：地下水環境保全を目的とした非排水構造卜 ンネルの地上注入工と掘削工. トンネル工学報告集,

23, 189-196.

篠崎知己（1976）: 異常出水とその対策 高千穂線高森

トンネル。トンネルと地下, 71, 7-14.

地盤工学会編（2004）：地下水流動保全のための環境影

響評価と対策. 地盤工学会, 375 .

茂利優一 - 中野将宏 - 原田博志 - 西垣 誠 - 長屋淳一 （2005）：第二京阪道路建設工事に扮ける地下水流動 阻害に関する検討，地下水環境に関するシンポジウ ム2005発表論文集, 55-62.

島田隆夫（1980）: 土被りの浅い山岳トンネルの地表沈 下. 土木学会論文集, 296, 97-110.

新宅良太・狩野浩資・景山浩孝・若杉俊一 (2012) :

中国自動車道尾道松江線大万木トンネルにおける

ウォータータイト構造における流域保全. 平成24年 度国土交通省国土技術研究会.

高橋彦治 (1963) : 湧水と地圧. 山海堂, 33-47.

高山 昭・芦田雄太郎（1972）：ウェルポイントによる

洪積層の掘さく.トンネルと地下, 21, 7-16.

竹内秀木 · 河上清和 · 折橋恒春 - 中川浩二 (1999) : 長 
尺鋼管フォアパイリング（AGF 工法）の効果に関す る研究. 土木学会論文集, No.623/VI-43, 233-246.

伊達健介 · 山本拓治 - 竹内仁哉 · 金沢智彦 (2014)：極

超微粒子セメントを利用したグラウト注入. 土木技 術, 69 (4), 22-27.

谷川 博 (2019) : 陥没の原因は不適切な掘削断面. 日 経コンストラクション, 6.24, 25.

玉川 清 - 野田博章 - 内田 毅 - 山田喜四夫 (1981)：

トンネル坑外仮設傭と環境対策 中国縦貫道牛頭トン

ネルほか.トンネルと地下, 125, 21-29.

田村 央 - 平田大輔 · 井上 啓 ·加藤宏征 (2012)：周 辺環境に配慮した止水注入とセグメントによる早期 覆工を採用－圈央道 高尾山トンネルー。トンネルと 地下, 43（10）, 7-14.

辻 正邦 - 小林伸司 - 佐藤稔紀 - 見掛信一郎 (2015)： 瑞浪超深地層研究所における大深度下でのグラウト 設計と施工実績㧍よび改良効果の評価. 第43回岩盤 力学に関するシンポジウム講演集, 公益社団法人土 木学会, 7-12.

辻 正邦 - 小林伸司 - 佐藤稔紀 - 見掛信一郎 (2016)： 瑞浪超深地層研究所における大深のポストグラウチ ング技術一新技術を導入した設計, 施工実績, 湧水抑 制効果の評価について一、第44回岩盤力学に関する シンポジウム講演集, 公益社団法人土木学会, 359364.

土木学会 (2007)：より良い山岳トンネルの事前調查,

事前設計に向けて.トンネルライブラリー, 18.

中出 剛 · 尾畑 洋 · 中川浩二 ·西垣 誠 (2017)：山

岳トンネルに扔ける地下水位低下制御工法とその評 価に関する一考察. 土木学会論文集 F1（トンネル工 学), 73 (1), 1-13.

中出 剛（2018）：山岳トンネルにおける環境保全に配 慮した地下水環境変化の抑制手法に関する研究. 岡 山大学大学院環境生命科学研究科博士論文, 51-83. 中出 剛·鈴木雅文·手塚 仁·古田島信義·片山政弘 · 木佐貫浄治・西垣 誠 (2019) : ポストグラウトに よる山岳トンネルの減水対策工法とトンネル挙動に 関する一考察. 土木学会論文集 F1 (トンネル工学), 75 (1), 75-87.

成田 望 (2017)：【技術報告】旭川十勝道路 富良野

市 北の峰トンネル工事. 建設クラブ, 2017年 1 月 号, 17.

西垣 誠・見掛信一郎 (2002) : 複数亀裂モデルにおけ
るグラウトの流動特性のメカニズムに関する研究. 土木学会論文集, No.715, III -60, 323-332.

西垣 誠 - 小松 満 ·見掛信一郎 ·田岡 洋 - 中島朋 宏(2004): エタノールを用いたベントナイトスラリー の亀裂性岩盤へのグラウト効果. 土木学会論文集,

No.764/ III -67, 221-233.

西垣 誠·今井紀和・小松 満・長井いづみ (2005):

圧縮を伴う比貯留係数の変化を考慮した地下水浸 透に基づく地盤沈下解析手法. 土木学会論文集,

No.799/ III -72, 1-12.

西垣 誠 - 小松 満 - 入江 彰・矢野耕一郎 -太田拓

郎 (2004)：山岳トンネル掘削時の地下水変動の簡易 的予測法と適用法. 土木学会論文集, No.778/ III -69, 125-137.

西垣 誠·金沢智彦・Larry ax Chegbeleh (2011)：セ メント系注入材料の注入によるしらす斜面崩壊防 止対策に関する検討. 地盤工学ジャーナル，6（2）, 213-224.

西垣 誠 · 柴田卓詞 · 加藤裕将 ·平田洋一 (2018) : 孔 内流速検層装置（フローメー夕検層）による多層带 水層の透水性評価. 地盤と建設, 36 (1)，65-70.

西垣 誠 - 柴田卓詞 · 加藤裕将 - 岩上 聡 - 平田洋一 （2020）: 流速計, 電気伝導度計及び温度計を有する 孔内マルチ検層装置による多層帯水層の地層評価. 地盤と建設, 37 (1). (掲載可)

早川敏彦・原繁之・西川直輝（1980）：地下水盆下の トンネル施工と水文調查 中央塩嶺トンネル. トンネ ルと地下, 114, 25-34.

平沢市郎 ·飯田 茂・森喬・山本松生 (1974)：立 坑の多量湧水と対策 上越新幹線中山トンネル四方木 立坑. トンネルと地下, 41, 46-57.

深谷 渉 - 野田康江 · 川島弘靖 - 平出亮輔 (2019)：下 水道管路起因の道路陥没. 地盤工学会誌, 67 (8), 8-11.

古家義信 - 五十嵐敏文・松本貴之 ·大川 了 (2012)： 大気中二酸化炭素を利用したアルカリ性トンネル湧 水の自然中和処理装置の構築. 土木学会論文集 $\mathrm{F} 1$ ( 卜 ンネル工学), 68 (2), 29-39.

前田武雄・亀沢勝治・田中伸夫（1978）: 国道19号のネッ クを解消 新鳥居トンネル. トンネルと地下, $99,25-$ 30 .

前田敏郎 · 岡本 弾 - 古田島信義 - 小林 翼 (2014)： 大山ダムの複列カーテングラウチングで実施した連 
続配合切替による超微粒子セメントのグラウチング 効果. ダム工学, 24 (4), 267-278.

見掛信一郎・池田幸喜・松井裕哉・辻 正邦 - 西垣誠

(2018)：高圧湧水下に㧍けるプレグラウチングとポ ストグラウチングを併用した湧水抑制効果の評価.

土木学会論文集 C (地圈工学), 74 (1), 76-91.

三谷泰浩（2019）：福岡市営地下鉄七隈線博多駅陥没事

故とその復旧工事. 地盤工学会誌, 67 (8), 4-7.

村上郁雄・大島洋志・塚本正雄 (1977) : 丹那トンネル

の湧水・渴水はどうなっているか. トンネルと地下,

$86,41-52$.

山本 健 - 澄田信夫 ·玉井信也 (1996) : 新熊見発電所 新設工事に扔ける水源枯渴対策. 電力土木, $263,16-$ 22.

山本拓治 - 佐藤秀史 ·齋藤宏樹 - 鹿嶋辰紀 - 伊達健介 横田泰宏・成田 望 (2016)：断層活動により破砕し た新第三紀泥岩のトンネル掘削における評価法. 応 用地質, 56 (6)，325-335.

山本裕司（2019）：台北地下鉄環状線 CF640工事-現地 職員の人材育成の取り組み一. 土木学会誌, 104 (8), 40-42.

吉村 昭 (2016): 闇を切り裂く道（上,下). 文集文庫, (1987年初版), 新装版, 515 .

Aram, M.(2016): Armenian and Euroean Methods of Tunnel Waterroofing. Int'l Journal of Research in Chemical, Metallurgical and Civil Engg.(IJRCMCE), 3 (1), 1-9.

Bear, J.(1972): Dynamics of Fluids in orous Media. Dover ublications Inc., 403-423.

Biot, M.A. (1941): General theory of three-dimensional consolidation. Journal of Alied hysics, 12, 155-164.

Dammyr, O.(2017): ressurized TBM-shield tunneling under the subsidence sensitive grounds of Oslo: ossivilities and limitations. Tunnelling and Underground Sace Technology, 47-55.

Gestafson, G. and H. Stille (2005): Sto criteria for cement grouting. Felsbau23, 3, 62-68.

Kobayashi, S., M.Soya, N.Takeuchi, J.Nobuto, A.
Nakaya, and T. Okuno(2014): Rock grouting and durability exeriments of colloidal silica at Kurashiki underground LG storage base. Rock Engineering and Rock Mechanics: Structures in and on Rock Masses Alejano, erucho, Olalla \& Jimenez(Eds), 1027-1032.

Kobayashi, S., T.Nobuto, H.Sugiyama, T.Kusano, K.Tsuji, S.Mikage and H.Matsui(2012): Grouting Exeriment with Collidal Silica at $300 \mathrm{~m}$ deth of the Mizunami URL. EUROCK2012, 1-13.

Kobayashi, S., M.Tsuji, M.Soya and K.Haruyama: Effect of comlex dynamic grouting with suer-fine cement and colloidal silica. EUROCK2015\&64 $4^{\text {th }}$ Geomechanics Colloquium.

Lemke, S., T. Aydogmus, A.T. Arslan and A. Tezel (2006): Tunneling Under Difficult Conditions -Waterroofing Systems. $8^{\text {th }}$ Regional Rock Mechanics Symosium, 1-7.

Meissner, M.(2013): Long term durable membrane solutions for waterroofing in drained and undrained tunnels - relevance of design and lanning, different membrane materials and influence of the quality of installation. GEOTECHNICAL ASECTS IN TUNNEL AND UNDERGROUND WORKS, 1-15.

Nishigaki, M., T. Imai, and A. Irie (2008): A numerical analysis method for redicting ground surface settlement caused by excavation of tunnels under ground water table. XXXVI IAH 2008 roceedings, 1-12.

Stille, B., H.Stille, G.Gustafson and S.Kobayashi(2015): Exerience with the real time grouting control method. Geomechanics and Tunnelling2, 5, 447-459.

Tsuji, M., J.Funehag, S.Kobayashi, T.Sato and S. Mikake(2014): Comarison of grouting with silica sol in the Aso Hard Rock Laboratory in Sweden and Mizunami Underground Research Laboratory in Jaan. $8^{\text {th }}$ Asian Rock Mechanics Symosium.

Wang, S.H., G.H. Huang and C. Zeng (2007): Research on Construction Technology for Yangtze-River Crossing Tunnel roject in Wuhan. Pipelines 2007.

(受付：2019年10月22日, 受理：2020年 2 月 5 日) 